\title{
The potential of deferasirox as a novel therapeutic modality in gastric cancer
}

\author{
Jung Hye Choi", Jung Soon Kim, Young Woong Won, Jieun Uhm, Byeong Bae Park and Young Yiul Lee
}

\begin{abstract}
Background: Iron is a crucial element for cell proliferation, growth, and metabolism. However, excess iron and altered iron metabolism are both associated with tumor initiation and tumor growth. Deferasirox is an oral iron chelator. Although some studies have indicated that deferasirox is a promising candidate for anti-cancer therapies, its effectiveness against gastric cancer has not yet been determined. This study was conducted to determine whether deferasirox exerts anti-tumor effects in gastric cancer cell lines and whether deferasirox and cisplatin act synergistically.

Methods: Four human gastric cancer cell lines (AGS, MKN-28, SNU-484, and SNU-638) were treated with various concentrations of deferasirox to determine the $I_{50}$ for each cell line. The effects of deferasirox on the cell cycle were evaluated by flow cytometry, and the effects of deferasirox on iron metabolism, the cell cycle, and apoptosis were assessed by Western blotting. To determine whether deferasirox enhances the effect of cisplatin, AGS cells were cultured in the presence and absence of cisplatin.

Results: Deferasirox inhibited the proliferation of all gastric cancer cell lines as assessed by MTT assays. Since the $\mathrm{IC}_{50}$ of deferasirox was the lowest (below $10 \mu \mathrm{M}$ ) in AGS cells, subsequent experiments were performed in this line. Deferasirox upregulated transferrin receptor 1 expression and decreased ferroportin expression. Moreover, deferasirox induced G1 arrest; upregulated p21, p27, and p53 expression; and downregulated cyclin D1, cyclin B, and CDK4 expression. Furthermore, deferasirox induced apoptosis, upregulated N-myc downstream regulated gene 1 (NDRG1), and downregulated p-mTOR and c-myc expression. It was also found to act synergistically with cisplatin.

Conclusions: Our results suggest that deferasirox may exert anti-tumor effects in the context of gastric cancer. Deferasirox affects a number of different pathways and molecules; for instance, deferasirox upregulates NDRG1 expression, inhibits the cell cycle, downregulates mTOR and c-myc expression, and induces apoptosis. In addition, deferasirox appears to potentiate the anti-cancer effects of cisplatin. Although the efficacy of deferasirox remains to be tested in future studies, the results presented here indicate that deferasirox is a promising novel anti-cancer therapeutic agent.
\end{abstract}

Keywords: Deferasirox, Stomach neoplasm, Cisplatin

\section{Background}

Gastric cancer is one of the leading causes of cancerrelated deaths in Korea [1]. Although patients with gastric cancer show excellent outcomes if the cancer is detected early, inoperable advanced and recurrent gastric cancers are still associated with poor survival rates. In the past few decades, substantial improvements in

\footnotetext{
* Correspondence: jhcmd@hanyang.ac.kr

Department of Internal Medicine, Hanyang University Guri Hospital, Hanyang

University College of Medicine, Guri-si, Gyeonggi-do 471-701, Republic of Korea
}

chemotherapeutic agents have improved survival in advanced gastric cancer. Recently, overall survival was significantly prolonged in patients with HER2-positive advanced gastric or gastro-esophageal junction cancer by treating with trastuzumab (HER-2 monoclonal antibody) in combination with conventional chemotherapy [2]. However, the overall survival was only 13.8 months. Therefore, new agents are urgently required.

Iron is an essential element for cell proliferation, growth, and metabolism. However, excess iron and altered iron metabolism have been associated with
(C) 2016 Choi et al. Open Access This article is distributed under the terms of the Creative Commons Attribution 4.0 International License (http://creativecommons.org/licenses/by/4.0/), which permits unrestricted use, distribution, and reproduction in any medium, provided you give appropriate credit to the original author(s) and the source, provide a link to the Creative Commons license, and indicate if changes were made. The Creative Commons Public Domain Dedication waiver (http://creativecommons.org/publicdomain/zero/1.0/) applies to the data made available in this article, unless otherwise stated.

C Biomed Central 
tumor initiation and tumor growth [3]. Epidemiological studies have revealed that a high iron intake is associated with an increased risk of colorectal cancer [4]. Many cancer cells alter iron metabolism because malignant cells require more iron than normal cells. To increase the labile iron pool, cancer cells have been shown to upregulate the expression of transferrin receptor 1 (TFR1) and hepcidin, in addition to downregulating ferroportin expression [3].

Deferasirox (Exjade $\left.{ }^{\circ}\right)$, an oral tridentate iron $\left(\mathrm{Fe}^{3+}\right)$ chelator, is rapidly absorbed from the gut and has a relatively long half-life ( 8 to $16 \mathrm{~h}$ ). Thus, once-daily dosing can achieve sustained circulating drug levels sufficient for the scavenging of non-transferrin-bound plasma iron. Although deferasirox has been associated with some adverse effects such as gastrointestinal disturbance, skin rash, and renal toxicity, it is relatively well tolerated. Therefore, deferasirox is currently the most commonly used iron chelator for the treatment of iron overload disease [5].

Recently, several studies have investigated the potential of deferasirox as an anti-neoplastic agent. Deferasirox has been reported to inhibit NF-kB activity in blood samples from patients with myelodysplastic syndrome and in leukemia cell lines [6]; moreover, deferasirox was also shown to repress the mTOR pathway in myeloid leukemia cells [7]. Regarding clinical data, one case report showed that deferasirox treatment achieved complete remission in patients with chemotherapyrefractory acute monocytic leukemia [8]. Furthermore, post hoc analysis of a multicenter trial revealed that deferasirox improved hematological parameters in patients with myelodysplastic syndrome [9]. At present, most reports of deferasirox as an anti-neoplastic agent have been in hematologic malignancies; only a few studies have focused on solid tumors. Recently, deferasirox was shown to inhibit the growth of lung and esophageal cancer cells both in vitro and in vivo $[10,11]$. However, the effect of deferasirox on gastric cancer has not yet been determined, and the mechanism by which deferasirox exerts its anti-tumor effects remains poorly understood. Therefore, this study was conducted to investigate whether deferasirox exerts anti-tumor effects on gastric cancer cell lines and also whether deferasirox acts synergistically with cisplatin.

\section{Methods}

\section{Cell culture}

Four human gastric cancer cell lines (AGS, MKN-28, SNU-484, and SNU-638) were obtained from the Korean Cell Line Bank. All cells were cultured in RPMI 1640 medium containing $10 \%$ fetal bovine serum and antibiotics $(100 \mathrm{U} / \mathrm{mL}$ penicillin and $100 \mu \mathrm{g} / \mathrm{mL}$ streptomycin) in a humidified $5 \% \mathrm{CO}_{2}$ incubator at $37{ }^{\circ} \mathrm{C}$.

\section{Reagents and antibodies}

Deferasirox $\left(\right.$ Exjade $^{\circ}$ ) was donated by Novartis (Basel, Switzerland). Goat polyclonal anti-NDRG1 (N-myc downstream regulated gene 1) (catalog no. ab37897) and rabbit polyclonal anti-ferroportin (catalog no. ab85370) antibodies were purchased from Abcam (Cambridge, UK). Anti-TFR1 mouse monoclonal antibodies (catalog no. 136800) were obtained from Life Technologies (Carlsbad, CA, USA), and $\mathrm{FeSO}_{4}$ was purchased from Sigma-Aldrich (St. Louis, MO, USA). Anti-p53, anti-p27, p21, cyclin A, cyclin B, cyclin D1, cyclin E, CDK2, CDK4, CDK6, c-myc, pro-caspase 3, and BAX antibodies were purchased from Santa Cruz Biotechnology (Santa Cruz, CA, USA). Anti-p-mTOR and pro-caspase 8 antibodies were obtained from Cell Signaling Technology (Beverly, MA, USA).

\section{Growth inhibition assay}

Growth inhibition was measured with MTT (3-[4,5dimethylthiazol-2-yl]-2,5-diphenyltetrazolium bromide) as previously described [12]. Briefly, cells were seeded $\left(2 \times 10^{3}\right.$ cells/well) in 96-well microtiter plates (Nunc, Roskilde, Denmark) and incubated at $37^{\circ} \mathrm{C}$ for 24,48 , or $72 \mathrm{~h}$. MTT solution $(50 \mu \mathrm{L})$ from Sigma $(2 \mathrm{mg} / \mathrm{mL}$ in PBS) was added to each well, and the plates were incubated for an additional $4 \mathrm{~h}$ at $37^{\circ} \mathrm{C}$. After this incubation, the MTT solution was aspirated off. To solubilize the formazan crystals formed in viable cells, $200 \mu \mathrm{L}$ of DMSO was added to each well. The plates were shaken for $30 \mathrm{~min}$ at room temperature, and the absorbance of each well at $595 \mathrm{~nm}$ was read immediately with a scanning multiwell spectrophotometer (Bio-Rad, iMarkTM microplate reader).

To determine the concentration of deferasirox required to kill $50 \%$ of the cells $\left(\mathrm{IC}_{50}\right)$, AGS, MKN-28, SNU-484, and SNU-638 cells were treated with 0, 1, 10, 50 , and $100 \mu \mathrm{M}$ of deferasirox for 24,48 , and $72 \mathrm{~h}$. These results were used to select the gastric cell line with the greatest sensitivity to deferasirox for all subsequent experiments.

\section{Cell cycle analysis}

After 24-h incubation of AGS cells with 0, 10, and $100 \mu \mathrm{M}$ of deferasirox at $37{ }^{\circ} \mathrm{C}$, the cells were washed twice with PBS, fixed overnight with $70 \%$ ethanol, washed with PBS, and stained with $50 \mu \mathrm{g} / \mathrm{mL}$ of propidium iodide (PI) containing RNase A at $50 \mu \mathrm{g} / \mathrm{mL}$. The DNA contents of the cells $(10,000$ cells/experimental group) were analyzed using a FACSCanto II flow cytometer (Becton Dickinson, San Jose, CA, USA) equipped with BD FACSDivaTM software (v6.1.3). The percentages of the cell populations in each cell cycle phase (G1, S, or G2/M) were calculated from the DNA content histograms. 


\section{Western blot analysis}

AGS cells were incubated with 0,10 , and $100 \mu \mathrm{M}$ of deferasirox at $37^{\circ} \mathrm{C}$ for $24 \mathrm{~h}$. The cells were washed with PBS, resuspended in lysis buffer [50 mM Tris (pH 7.5), 1 \% NP-40, $2 \mathrm{mM}$ EDTA, $10 \mathrm{mM} \mathrm{NaCl}, 20 \mu \mathrm{g} / \mathrm{mL}$ aprotinin, $20 \mu \mathrm{g} / \mathrm{mL}$ leupeptin, and $1 \mathrm{mM}$ phenylmethylsulfonyl fluoride], and placed on ice for $20 \mathrm{~min}$. Proteins in the lysates $(20-30 \mu \mathrm{g})$ were resolved on 10-15\% SDS-polyacrylamide denaturing gels and transferred to nitrocellulose membranes for 90$120 \mathrm{~min}$. Nonspecific binding sites were blocked with $5 \%$ skim milk for $1 \mathrm{~h}$, and the membranes were then incubated overnight with primary antibodies (all at a 1:1000 dilution). The antibodies and the related processes that were used to investigate were as follows: anti-TFR1 and anti-ferroportin for iron metabolism; anti-p53, p27, p21, cyclin A, cyclin B, cyclin D1, cyclin E, CDK2, CDK4, and CDK6 for the cell cycle; anti-pro-caspase 3 , pro-caspase 8 , procaspase 9, and BAX for apoptosis; anti-NDRG1 for metastasis; and anti-p-mTOR and c-myc. Immunoreactive bands were visualized with an ECL kit (Intron, Korea).

\section{Statistical analysis}

Data are presented as means \pm SEMs (error bars). Differences were analyzed with Student's $t$ test. $P$ values $<0.05$ were considered statistically significant.

\section{Results}

Effect of deferasirox on the growth of gastric cancer cell lines

The ability of deferasirox to inhibit the growth of the four gastric cancer cell lines was determined by an MTT proliferation assay. AGS, MKN-28, SNU-484, and SNU-638 cells were incubated with $0,1,10,50$, and $100 \mu \mathrm{M}$ deferasirox at $37^{\circ} \mathrm{C}$ for 24,48 , or $72 \mathrm{~h}$. Deferasirox inhibited the growth of all four gastric cancer cell lines in a dosedependent and time-dependent manner (Fig. 1a). Since the $\mathrm{IC}_{50}$ of deferasirox at $72 \mathrm{~h}$ was the lowest in AGS cells (less than $10 \mu \mathrm{M}$ ), all subsequent experiments were performed using these cells.

AGS cells were cultured with 10 and $20 \mu \mathrm{M}$ of deferasirox either alone or in the presence of $\mathrm{FeSO}_{4}(100 \mu \mathrm{M})$ for $48 \mathrm{~h}$. The inhibitory effect of deferasirox was reversed by $\mathrm{FeSO}_{4}$ supplement (Fig. 1b).

\section{Cell cycle analysis in AGS cells}

Iron depletion induces G1/S arrest by affecting the expression of critical molecules for cell cycle progression such as cyclin D1 and p21 [13]. The effects of deferasirox on the cell cycle were determined by fluorescenceactivated cell sorting (FACS) using propidium iodide. AGS cells were incubated with 0,10 , and $100 \mu \mathrm{M}$ of
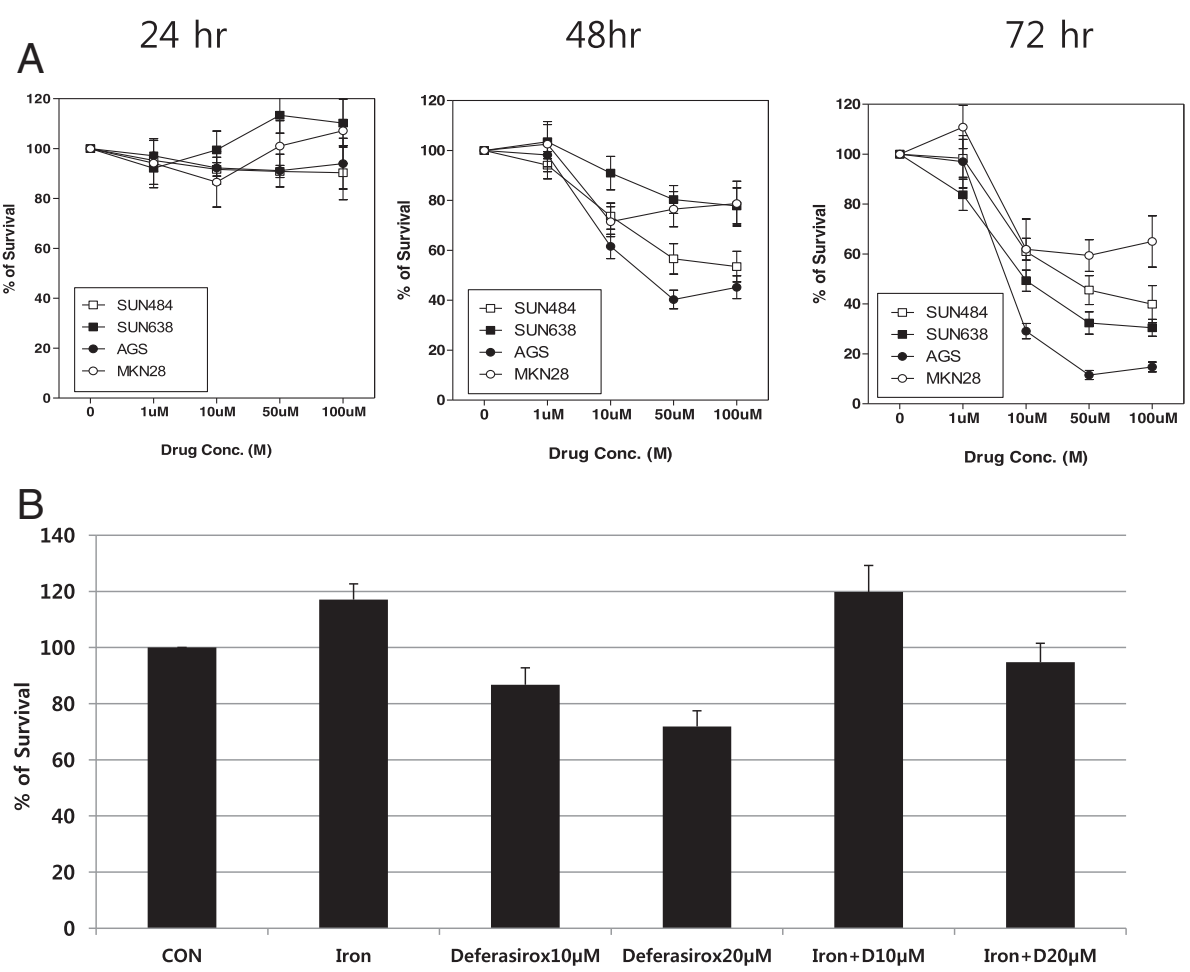

Fig. 1 Inhibitory effect of deferasirox on the growth of gastric cancer cell lines. a Cell viability was measured by the MTT assay. AGS, MKN-28, SNU-484, and SNU-638 cells were incubated with $0,1,10,50$, and $100 \mu \mathrm{M}$ of deferasirox at $37^{\circ} \mathrm{C}$ for 24 , 48 , or $72 \mathrm{~h}$. Deferasirox treatment resulted in dose-dependent and time-dependent growth inhibition in all four gastric cancer cell lines. b AGS cells were cultured with 10 and $20 \mu \mathrm{M}$ of deferasirox either alone or in the presence of $\mathrm{FeSO}_{4}(100 \mu \mathrm{M})$ for $48 \mathrm{~h}$. The inhibitory effect of deferasirox was reversed by FeSO $\mathrm{supplement}$ 
deferasirox at $37{ }^{\circ} \mathrm{C}$ for $24 \mathrm{~h}$. As shown in Fig. 2a, treatment of AGS cells with deferasirox for $24 \mathrm{~h}$ led to an accumulation of cells in G1 phase in a dose-dependent manner $(41.8 \%$ at $0 \mu \mathrm{M}, 53.7 \%$ at $10 \mu \mathrm{M}$, and $77.2 \%$ at $100 \mu \mathrm{M})$. This result indicates that deferasirox induces G1 arrest. Western blot analysis of cell cycle-related proteins showed that deferasirox induced the upregulation of p21, p27, and p53, and the downregulation of cyclin D1, cyclin B, and CDK4 (Fig. 2b). These results suggest that the anti-proliferative effect of deferasirox is due to cell cycle inhibition.

\section{Effect of deferasirox on iron metabolism and other pathways}

For iron uptake into the cell, circulating iron-transferrin complexes bind to the cell surface receptor TFR1. Iron exits via ferroportin, an iron efflux pump that is regulated by hepcidin. In cancer cells, TFR1 and hepcidin have been shown to be upregulated and ferroportin is downregulated, which cumulatively lead to increased concentrations of intracellular iron [3]. The effect of deferasirox on iron metabolism was evaluated by Western blot analysis of TFR1 and ferroportin. The level of TFR1 increased after $24 \mathrm{~h}$ of treatment with deferasirox. In contrast, ferroportin expression decreased (Fig. 3a). These results are consistent with those of previous studies $[10,11]$.

The effects of deferasirox on apoptosis were next evaluated by FACS and Western blot analysis of apoptosisrelated proteins. As shown in Fig. 2a, AGS cells treated with deferasirox for $24 \mathrm{~h}$ exhibited an accumulation of cells in sub-G1 (apoptotic) phase $(3.2 \%$ at $0 \mu \mathrm{M}, 3.3 \%$ at $10 \mu \mathrm{M}$, and $9.5 \%$ at $100 \mu \mathrm{M})$. Moreover, deferasirox treatment decreased the expression of pro-caspase 3, pro-caspase 8 , and pro-caspase 9 and increased the expression of BAX (Fig. 3b). NDRG1 is known to be a suppressor of cell growth and metastasis. Deferasirox increased the level of NDRG1. In addition, c-myc and
phospho-mTOR expression were decreased after $24 \mathrm{~h}$ of treatment with deferasirox (Fig. 3b). These results suggest that deferasirox induces apoptosis, inhibits distant metastasis, and suppresses the c-myc and mTOR pathways.

\section{Synergistic effect of deferasirox and cisplatin}

To assess whether deferasirox could enhance the effect of cisplatin, AGS cells were cultured with or without cisplatin and their viability was determined using the MTT assay. Treatment with cisplatin for $48 \mathrm{~h}$ reduced the number of viable cells, with an $\mathrm{IC}_{50}$ of $5-10 \mu \mathrm{M}$. To determine whether deferasirox exerts a synergistic effect with cisplatin, AGS cells were treated with $0,2.5,5,10$, and $20 \mu \mathrm{M}$ of deferasirox either alone or in the presence of a fixed concentration of cisplatin $(5 \mu \mathrm{M})$ for $48 \mathrm{~h}$. As shown in Fig. 4a, b, AGS cells treated with deferasirox and cisplatin showed a significantly greater decrease in cellular viability compared with cells treated with either deferasirox or cisplatin alone $(P<0.01)$. These results suggest that deferasirox enhances cisplatin-mediated inhibition of AGS cell growth.

To investigate the molecular mechanisms underlying this effect, Western blot analysis was used to assess the levels of various molecules in AGS cells treated with deferasirox $(5 \mu \mathrm{M})$, cisplatin $(5 \mu \mathrm{M})$, or both. The combination of deferasirox and cisplatin resulted in the upregulation of NDRG1, p21, and p53. In contrast, this combination resulted in the downregulation of phosphomTOR, ferroportin, and pro-caspase 9. These findings suggest that deferasirox potentiates the anti-cancer effects of cisplatin through various pathways (Fig. 5).

\section{Discussion}

In this study, we found that deferasirox inhibits the proliferation of gastric cancer cells. Deferasirox was also found to induce G1 arrest; upregulate p21, p27, and p53 expression; and downregulate cyclin D1, cyclin B, and
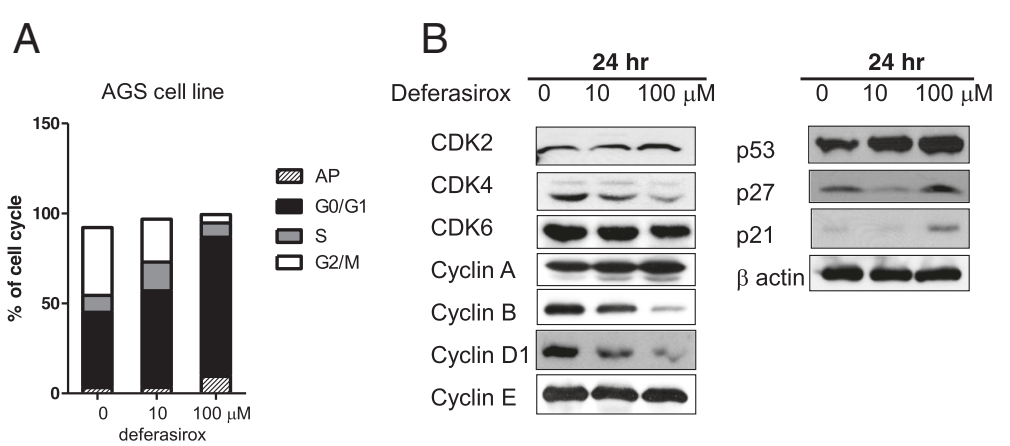

Fig. 2 Effect of deferasirox on cell cycle progression in AGS cells. a AGS cells were incubated with 0 , 10, and $100 \mu \mathrm{M}$ of deferasirox at $37^{\circ} \mathrm{C}$ for $24 \mathrm{~h}$. Cell cycle progression was analyzed by FACS. Deferasirox treatment for $24 \mathrm{~h}$ led to a dose-dependent accumulation of AGS cells in G1 phase ( $41.8 \%$ at $0 \mu \mathrm{M}, 53.7 \%$ at $10 \mu \mathrm{M}$, and $77.2 \%$ at $100 \mu \mathrm{M}$ ). b Western blot analysis of cell cycle-related molecules showed that deferasirox upregulated p21, p27, and p53 and downregulated cyclin D1, cyclin B, and CDK4 
A

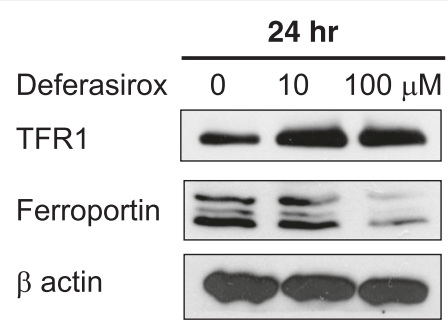

B

$24 \mathrm{hr}$

$24 \mathrm{hr}$

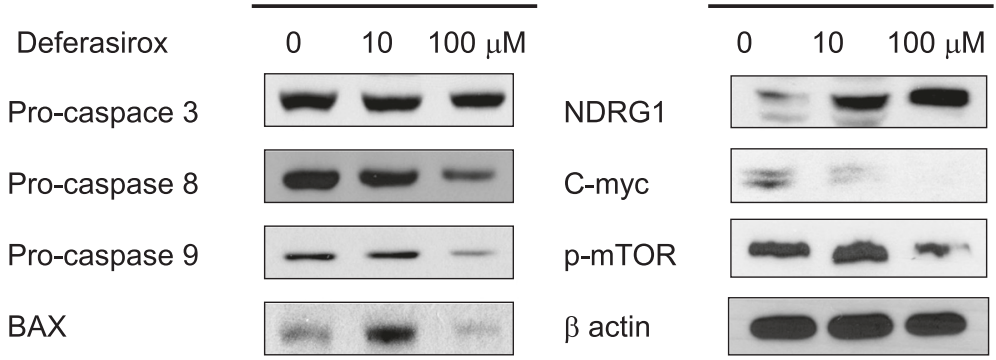

Fig. 3 Effect of deferasirox on iron metabolism and other pathways. a Treatment with deferasirox for $24 \mathrm{~h}$ resulted in an increased level of TFR1 and a decreased level of ferroportin. $\mathbf{b}$ Deferasirox also induced apoptosis, upregulated NDRG1, and downregulated p-mTOR and c-myc as assessed by Western blot analysis

CDK4 expression. Deferasirox also induced apoptosis, upregulated NDRG1, and downregulated p-mTOR and c-myc. These results suggest that deferasirox exerts antitumor effects in gastric cancer cells via various pathways. Specifically, our data indicate that deferasirox alters iron metabolism, inhibits cell cycle progression, affects mTOR signaling and metastasis pathways, and induces apoptosis. In addition, deferasirox appears to potentiate the anti-proliferative effect of cisplatin in stomach cancer cells.

Iron is essential for cell survival but can also cause cellular damage by generating reactive oxygen species [14]. Although the level of intracellular iron is tightly regulated in normal cells, the level of intracellular iron is elevated in cancer cells due to increased expression of TFR1 and hepcidin and reduced expression of ferroportin [3]. Since excess iron and altered iron metabolism can lead to tumor initiation and growth, iron chelators are believed to be promising anti-cancer agents. Several lines of evidence support the idea that iron chelators are potential anti-tumor therapeutics. Firstly, increased levels of intracellular iron are known to promote DNA synthesis. Since iron is essential for the activity of ribonucleotide reductase, a key enzyme for DNA synthesis, iron plays an important role in cell proliferation [15]. Therefore, increased iron is required to augment ribonucleotide reductase activity in neoplastic cells. Secondly, iron depletion can cause G1/S arrest and induce apoptosis [13]. Cyclin D1
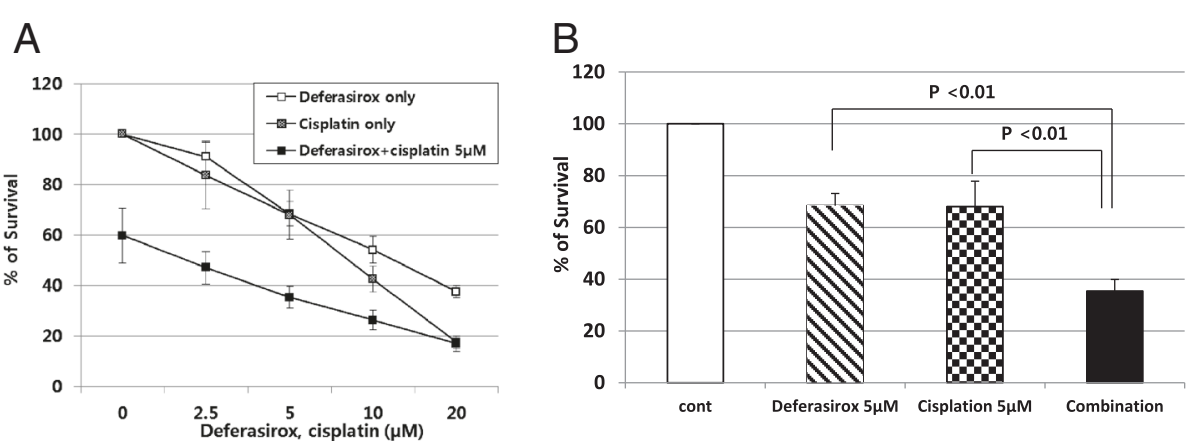

Fig. 4 Synergistic effect of deferasirox and cisplatin. a, b AGS cells were treated with 0, 2.5, 5, 10, and $20 \mu \mathrm{M}$ of deferasirox, either alone or in the presence of a fixed concentration of cisplatin $(5 \mu \mathrm{M})$ for $48 \mathrm{~h}$. AGS cells treated with deferasirox and cisplatin showed a significant decrease in cellular viability compared with cells treated with either deferasirox or cisplatin alone 


\begin{tabular}{|l} 
Deferasirox $(5 \mu \mathrm{M})$ \\
Cisplatin $(5 \mu \mathrm{M})$ \\
$\mathrm{NDRG} 1$
\end{tabular}

binds to CDK4 and CDK6, thereby resulting in G1/S progression via phosphorylation of retinoblastoma protein (RB). This phosphorylation in turn results in the release of the transcription factor E2F from RB. Iron depletion is known to decrease cyclin D1 and CDK expression. Thirdly, excessive cellular iron can drive the Wnt signaling pathway, which is known to be important for tumor progression [16].

We performed this study to investigate whether deferasirox exerts anti-tumor effects in the context of gastric cancer. We chose deferasirox out of the numerous commercially available iron chelators due to its oral availability and relatively low toxicity. Although the precise mechanisms by which deferasirox exerts its anti-cancer effects are still being investigated, we hypothesized that deferasirox inhibits cell cycle progression based on previous studies [11, 17]. We found that deferasirox induced G1 arrest by upregulating p21 and p27 and downregulating cyclin D1 and CDK4. These findings support our hypothesis that deferasirox exerts its antineoplastic effects by regulating cell cycle progression.

Iron chelators can induce the expression of NDRG1, a known metastatic suppressor, in a variety of human cancers [18-20]. The mechanism by which NDRG1 suppresses metastasis is presently unclear, although NDRG1 has been shown to inhibit cell migration and invasion by modulating the expression of a number of adhesion molecules [21]. NDRG1 expression has been shown to be significantly lower in cancer tissue compared with adjacent normal tissue; moreover, NDRG1 expression has been shown to be inversely correlated with the metastasis of some cancers, such as prostate and colorectal cancer [22, 23]. However, discrepant results have been obtained regarding a possible association of NDRG1 with tumor progression. Interestingly, NDRG has a demonstrated role in cell cycle control. Specifically, NDRG1 expression is upregulated via p53-mediated induction, and NDRG1 can also induce G1/S arrest by upregulating p21 [24]. We found that deferasirox upregulates the expression levels of NDRG1, p53, and p21. Although we did not assay cell migration or investigate metastasis in vivo in the present study, our findings suggest that deferasirox may be able to inhibit tumor growth and metastasis. We hypothesize that the mechanism by which deferasirox exerts its anti-tumor effects may involve NDRG1.

Deferasirox has been shown to enhance the cytotoxic effect of cisplatin in esophageal cancer cell lines. In addition, cisplatin-resistant cells treated with a low concentration of deferasirox $(5 \mu \mathrm{M})$ in combination with cisplatin showed a significant reduction in cellular viability compared with cells treated with deferasirox or cisplatin alone [10]. We found that the combination of deferasirox $(5 \mu \mathrm{M})$ and cisplatin $(5 \mu \mathrm{M})$ induced a significant decrease in cellular viability. Moreover, this combined treatment resulted in the upregulation of NDRG1, p21, and p53 and the downregulation of phospho-mTOR. Our results, therefore, suggest that deferasirox can potentially enhance the anti-cancer effect of cisplatin in gastric cancer cells. Moreover, the p53NDRG1-p21 and mTOR pathways may be involved in the synergistic effect of deferasirox with cisplatin.

This study did have a number of limitations. Firstly, we restricted our study to gastric cancer cell lines and did not perform any in vivo experiments. In addition, the expression of cell cycle-related proteins was assessed only by Western blotting. More detailed information could have been obtained by immunoprecipitation and kinase assays. To determine the anti-tumor effect of deferasirox, additional experiments including in vivo study would be needed. Nevertheless, this is the first study to investigate the anti-tumor effects of deferasirox against gastric cancer. 


\section{Conclusions}

In conclusion, we found that deferasirox induced antitumor effects in gastric cancer cells via various pathways. Specifically, deferasirox upregulated NDRG1, inhibited cell cycle progression, downregulated mTOR and c-myc expression, and induced apoptosis. Moreover, deferasirox potentiated the anti-cancer effects of cisplatin. Although the efficacy of deferasirox must be confirmed in future studies, our results indicate that deferasirox is a promising anti-cancer therapeutic agent and may also be an effective chemotherapy sensitizer.

\section{Competing interests}

The authors declare that they have no competing interests.

\section{Authors' contributions}

$J C$ and $Y L$ participated in the design and analysis of the present research. JC wrote the paper. JK carried out the molecular studies. YW, JU, BP contributed in the composition of the paper. All authors read and approved the manuscript.

\section{Acknowledgements}

This work was supported by the research fund of Hanyang University (HY-2013-MC).

\section{Received: 4 August 2015 Accepted: 1 March 2016}

Published online: 10 March 2016

\section{References}

1. Jung KW, Won YJ, Kong HJ, Oh CM, Lee DH, Lee JS. Cancer statistics in Korea: incidence, mortality, survival, and prevalence in 2011. Cancer Res Treat. 2014;46:109-23.

2. Bang YJ, Van Cutsem E, Feyereislova A, Chung HC, Shen L, Sawaki A, et al. Trastuzumab in combination with chemotherapy versus chemotherapy alone for treatment of HER2-positive advanced gastric or gastrooesophageal junction cancer (ToGA): a phase 3, open-label, randomised controlled trial. Lancet. 2010;376:687-97.

3. Torti SV, Torti FM. Iron and cancer: more ore to be mined. Nat Rev Cancer. 2013;13:342-55.

4. Nelson RL. Iron and colorectal cancer risk: human studies. Nutr Rev. 2001;59:140-8

5. Cappellini MD, Cohen A, Piga A, Bejaoui M, Perrotta S, Agaoglu L, et al. A phase 3 study of deferasirox (ICL670), a once-daily oral iron chelator, in patients with beta-thalassemia. Blood. 2006;107:3455-62.

6. Messa E, Carturan S, Maffe C, Pautasso M, Bracco E, Roetto A, et al. Deferasirox is a powerful NF-kappaB inhibitor in myelodysplastic cells and in leukemia cell lines acting independently from cell iron deprivation by chelation and reactive oxygen species scavenging. Haematologica. 2010;95:1308-16.

7. Ohyashiki JH, Kobayashi C, Hamamura R, Okabe S, Tauchi T, Ohyashiki K. The oral iron chelator deferasirox represses signaling through the mTOR in myeloid leukemia cells by enhancing expression of REDD1. Cancer Sci. 2009;100:970-7.

8. Fukushima T, Kawabata H, Nakamura T, Iwao H, Nakajima A, Miki M, et al. Iron chelation therapy with deferasirox induced complete remission in a patient with chemotherapy-resistant acute monocytic leukemia. Anticancer Res. 2011;31:1741-4

9. List AF, Baer MR, Steensma DP, Raza A, Esposito J, Martinez-Lopez N, et al. Deferasirox reduces serum ferritin and labile plasma iron in RBC transfusiondependent patients with myelodysplastic syndrome. J Clin Oncol. 2012;30:2134-9.

10. Ford SJ, Obeidy P, Lovejoy DB, Bedford M, Nichols L, Chadwick C, et al. Deferasirox (ICL670A) effectively inhibits oesophageal cancer growth in vitro and in vivo. Br J Pharmacol. 2013;168:1316-28.

11. Lui GY, Obeidy P, Ford SJ, Tselepis C, Sharp DM, Jansson PJ, et al. The iron chelator, deferasirox, as a novel strategy for cancer treatment: oral activity against human lung tumor xenografts and molecular mechanism of action. Mol Pharmacol. 2013;83:179-90.
12. Campling BG, Pym J, Galbraith PR, Cole SP. Use of the MTT assay for rapid determination of chemosensitivity of human leukemic blast cells. Leuk Res. 1988;12:823-31.

13. Le NT, Richardson DR. The role of iron in cell cycle progression and the proliferation of neoplastic cells. Biochim Biophys Acta. 2002;1603:31-46.

14. Kehrer JP. The Haber-Weiss reaction and mechanisms of toxicity. Toxicology. 2000;149:43-50.

15. Kolberg M, Strand KR, Graff P, Andersson KK. Structure, function, and mechanism of ribonucleotide reductases. Biochim Biophys Acta. 2004;1699:1-34.

16. Brookes MJ, Boult J, Roberts K, Cooper BT, Hotchin NA, Matthews G, et al. A role for iron in Wnt signalling. Oncogene. 2008;27:966-75.

17. Yu Y, Gutierrez E, Kovacevic Z, Saletta F, Obeidy P, Suryo Rahmanto Y, et al. Iron chelators for the treatment of cancer. Curr Med Chem. 2012;19:2689-702.

18. Bae DH, Jansson PJ, Huang ML, Kovacevic Z, Kalinowski D, Lee CS, et al. The role of NDRG1 in the pathology and potential treatment of human cancers. J Clin Pathol. 2013;66:911-7.

19. Kovacevic Z, Richardson DR. The metastasis suppressor, Ndrg-1: a new ally in the fight against cancer. Carcinogenesis. 2006;27:2355-66.

20. Whitnall M, Howard J, Ponka P, Richardson DR. A class of iron chelators with a wide spectrum of potent antitumor activity that overcomes resistance to chemotherapeutics. Proc Natl Acad Sci U S A. 2006;103:14901-6.

21. Chen Z, Zhang D, Yue F, Zheng M, Kovacevic Z, Richardson DR. The iron chelators Dp44mT and DFO inhibit TGF-beta-induced epithelialmesenchymal transition via up-regulation of N-Myc downstream-regulated gene 1 (NDRG1). J Biol Chem. 2012;287:17016-28.

22. Bandyopadhyay S, Pai SK, Gross SC, Hirota S, Hosobe S, Miura K, et al. The Drg-1 gene suppresses tumor metastasis in prostate cancer. Cancer Res. 2003:63:1731-6.

23. Mao Z, Sun J, Feng B, Ma J, Zang L, Dong F, et al. The metastasis suppressor, N-myc downregulated gene 1 (NDRG1), is a prognostic biomarker for human colorectal cancer. PLoS One. 2013;8:e68206.

24. Kovacevic Z, Sivagurunathan S, Mangs H, Chikhani S, Zhang D, Richardson DR. The metastasis suppressor, $\mathrm{N}$-myc downstream regulated gene 1 (NDRG1), upregulates p21 via p53-independent mechanisms. Carcinogenesis. 2011:32:732-40.

Submit your next manuscript to BioMed Central and we will help you at every step:

- We accept pre-submission inquiries

- Our selector tool helps you to find the most relevant journal

- We provide round the clock customer support

- Convenient online submission

- Thorough peer review

- Inclusion in PubMed and all major indexing services

- Maximum visibility for your research

Submit your manuscript at www.biomedcentral.com/submit 